\title{
Associations Between Adverse Childhood Experiences and Adult Health Outcomes: Exploring Gender Differences
}

\author{
Hana Lee ${ }^{1}$, Ick-Joong Chung ${ }^{2}$ \\ Postdoctoral Researcher, Department of Social Welfare, Ewha Womans University, Seoul, Korea ${ }^{1}$ \\ Professor, Department of Social Welfare, Ewha Womans University, Seoul, Korea ${ }^{2}$ \\ 아동기 부정적 생애경험과 성인기 건강 간의 관계: 성별 차이의 탐색 \\ 이하나 ${ }^{1}$, 정익중 ${ }^{2}$ \\ 이화여자대학교 사회복지학과 박사후연구원 ${ }^{1}$ 이화여자대학교 사회복지학과 교수 ${ }^{2}$
}

\begin{abstract}
Objectives: This study aimed to (1) understand the associations between Adverse Childhood Experiences (ACEs) and poor adult health outcomes, specifically looking at both physical and mental health indicators, and (2) examine gender differences in ACEs' impact on adult health outcomes.

Methods: Data were obtained from the 2012 Korean General Social Survey. The study sample comprised 1,396 individuals aged $\geq 18$ years who answered the ACE questionnaire. Controlling for sociodemographic factors, linear regression models were run to estimate the relationships between ACEs and adult physical (self-rated poor physical health status) and mental health indicators (depressive symptoms). Furthermore, the Chow test was carried out to ascertain whether there were any gender differences in ACEs' impact on both adult physical and mental health outcomes.

Results: Higher numbers of ACEs were significantly and positively associated with worse adult physical and mental health outcomes, such as poorer physical health status and higher levels of depressive symptoms compared with individuals who reported no adversities during childhood. In addition, gender differences were identified in ACEs' impact on both health indicators, suggesting that females were at a higher risk of depression, while males were more likely to experience poor physical health.

Conclusion: Adults reporting multiple adversities during childhood are more likely to experience poorer physical and mental health, demonstrating a strong, graded dose-response relationship between the number of ACEs and a range of negative adult health outcomes. Gender differences also exist in ACEs' impact on adult physical and mental health, thus suggesting the need for gender-based intervention strategies to address ACEs in the adult population.
\end{abstract}

Keywords: Adverse Childhood Experiences (ACEs), adult physical health, depression, gender differences

\section{Introduction}

아동기 부정적 생애경험(Adverse Childhood Experiences [ACEs]) 은 일반적으로 만 18 세 이전에 겪은 다양한 역경을 포함하는

Corresponding Author: Ick-Joong Chung, Professor, Department of Social Welfare, Ewha Womans University, 52, Ewhayeodae-gil, Seodaemun-gu, Seoul, Korea

E-mail: ichung@ewha.ac.kr
포괄적인 개념으로써, 학대(신체, 정서, 성적), 방임(신체, 정서), 그리고 가족역기능(가정폭력, 부모의 이혼 혹은 별거, 가족 구 성원의 정신질환 혹은 알코올 중독 등) 등을 포함한다(Centers for Disease Control and Prevention [CDC], 2021). 아동기 부정

(C)The Korean Association of Child Studies

This is an Open Access article distributed under the terms of the Creative Commons Attribution Non-Commercial License (http:// creativecommons.org/licenses/by-nc/4.0) which permits unrestricted noncommercial use, distribution, and reproduction in any medium, provided the original work is properly cited. 
적 생애경험(ACEs)에 대한 대표적인 실증적 연구는 미국 질병 관리센터(CDC)와 캘리포니아 소재 의료서비스회사인 Kaiser Permanente에서 1995년에서 1997년까지, 즉 2년간 약 17,000여 명의 성인 의료보험 가입자를 대상으로 아동기에 겪었던 다양 한 부정적인 생애경험 및 건강 상태 등의 조사를 시작으로 현재 까지 $\mathrm{ACE}$ 와 성인의 건강 간의 관련성에 대한 연구가 활발히 이 루어지고 있다(CDC, 2021; Felitti et al., 1998).

아동기 부정적 생애경험은 유전자 발현, 뇌의 구조, 호르몬 체계, 혹은 면역 체계 등과 같은 인체의 생리적 - 생물학적 시 스템에 있어서 부정적인 후생적 변화들을 야기할 뿐만 아니 라, 사회정서적 - 인지적 - 행동적 체계 발달의 지체와 관련이 있기 때문에 이러한 비정상적 변형들과 지체가 지속되고 누적 되면 이후 신체의 마모나 손상, 더 나아가 심각한 건강문제가 발생하는 단계까지 이르게 한다(H. Lee, Boyd, \& Slack, in press; McEwen \& Gianaros, 2010; Shonkoff et al., 2012). 따라서, 아동 기 부정적 생애경험이 이후 성인기의 건강 및 웰빙(well-being) 에 심각한 영향을 줄 수 있기 때문에 공공 보건 및 생애주기적 관점에서 $\mathrm{ACE}$ 관련 연구의 필요성이 더욱 부각된다.

1990년대 후반부터 현재까지 이루어진 국외 ACE 연구들 을 살펴보면, 일반적으로 아동기 부정적 생애경험의 조작화에 있어서, 다양한 역경을 합산한 누적 횟수(cumulative number) 를 통해 아동기에 겪은 부정적 생애경험의 수와 이후 성인 기 건강 및 복지에 어떠한 영향을 주는지를 분석하는 실증 연 구들이 많은 비중을 차지한다. 이를 단계별 용량-반응 관계 (a graded dose-response relationship)라고 일컫는데(Felitti et al., 1998; Loxton et al., 2021; Merrick et al., 2017), 어린 시절 겪었던 역경 경험의 개수가 많을수록, 성인이 되었을 때 겪는 부정적 인 건강에 대한 위험성이 높아짐을 의미한다. 예를 들어, $\mathrm{ACE}$ 와 성인기의 부정적인 신체건강 간의 관계를 분석한 연구들을 살펴보면, 어린 시절 겪은 역경의 개수가 높을수록 성인이 되 었을 때 빈번한 두통(Anda, Tietjen, Schulman, Felitti, \& Croft, 2010), 좋지 못한 건강상태(Chartier, Walker, \& Naimark, 2010; Loxton et al., 2021; Reuben et al., 2016), 수면 장애(Chapman et al., 2011), 혹은 자가면역질환, 천식, 관동맥성심장병, 폐질환, 당뇨병 등과 같은 만성적인 질병(Anda et al., 2008; Brown et al., 2010; Downey, Gudmunson, Pang, \& Lee, 2017; Dube et al., 2009; Gilbert et al., 2015; Ittoop, Jefferey, Cheng, \& Reddy, 2020) 에 대한 위험성이 높아지는 등 아동기 부정적 생애경험의 누 적 개수와 성인의 부정적인 신체 건강지표 간의 상당히 의미 있는 관계성을 밝혔다.

이와 더불어, $\mathrm{ACE}$ 와 성인기의 정신건강 간의 관계를 분석
한 선행 연구들 또한 단계별 용량-반응 관계를 입증하였다. 예 를 들어, 아동기의 역경 개수가 높을수록 우울증상(Bonomi, Cannon, Anderson, Rivara, \& Thompson, 2008; Chapman et al., 2004; Dagnino et al., 2020; Danese et al., 2009; Downey et al., 2017; Espeleta et al., 2020; Font \& Maguire-Jack, 2016; Merrick et al., 2017; Racine et al., 2021), 불안장애(Cambron, Gringery, $\&$ Vogel-Ferguson, 2014), 외상후스트레스 장애(Cambron et al., 2014; LeardMann, Smith, \& Ryan, 2010), 양극성 기분장애 (Cambron et al., 2014), 혹은 자살시도(Merrick et al., 2017) 등 과 같이 정신건강과 관련한 문제들의 위험성이 높아지는 것으 로 나타났다. 이와 같이, $\mathrm{ACE}$ 와 성인기의 전반적인 건강 및 웰 빙의 연관성에 대해 국외에서는 방대하게 관련 연구들이 지속 적으로 수행되고 있다.

반면, 국내에서는 ACE에 대한 실증적 연구가 상대적으로 부족한 것으로 보인다. 2018년 한국보건사회연구원에서 발간 한 '생애주기별 학대 경험 연구' 보고서에 따르면, 18 세 미만 의 자녀가 있는 가정을 상대로 부모의 부정적 경험에 대한 실 태조사를 한 결과 주 양육자 전체 $(N=1,515)$ 의 약 $79.3 \%$ 가 적 어도 한 가지 이상의 아동기 부정적 경험이 있는 것으로 나타 났다(Ryu et al., 2018). 이렇듯, 국내에서 성인의 아동기 부정적 생애경험의 비율이 꽤 높게 나타나고 있음에도 불구하고 현재 손에 꼽힐 만큼 $\mathrm{ACE}$ 와 성인 건강에 대한 연구의 수가 제한적 이다. 그 예로 아동기 부정적 생애경험과 성인기의 우울증상 (Y. H. Kim, 2017; S.-S. Kim, Jang, Chang, Park, \& Lee, 2013; M. H. Lee \& Kim, 2017; Park \& Chung, 2018), 외상후스트레스 장 애(Son, Kim, \& Kim, 2018), 자살시도(J. Kim \& Son, 2020) 등 에 관한 연구들이 대표적이다. 이 연구들은 공통적으로 $\mathrm{ACE}$ 와 성인의 정신건강문제 등과 밀접한 관련이 있는 지표들을 분석하였으나, 상대적으로 신체적 건강을 다루는 연구는 아직 까지 없는 것으로 보인다.

또한, 국외 $\mathrm{ACE}$ 연구들을 살펴보면 기본적인 메커니즘으 로 $\mathrm{ACE}$ 와 성인의 웰빙지표 간의 관계성 입증에서 더 나아가 성인의 건강에 있어서 $\mathrm{ACE}$ 의 영향력에 대한 성별 차이(FullerThomson, Filippelli, \& Lue-Crisostomo, 2013; Giano, Wheeler, \& Hubach, 2020; Kelly-Irving et al., 2013) 혹은 아동기 혹은 성 인기의 긍정적 생애경험에 대한 조절효과(Bellis et al., 2017; Bethell, Jones, Gombojav, Linkenbach, \& Sege, 2019; H. Lee et al., in press) 등을 심층적으로 분석하는 등 연구의 질적인 부분 에서도 국내 $\mathrm{ACE}$ 연구를 훨씬 앞서나가고 있는 실정이다.

특히 ACE가 이후 성인의 건강에 끼치는 영향에 있어서 남 녀의 차이를 분석한 국외 연구의 결과들을 살펴보면 흥미로운 
점들을 발견할 수 있다. ACE 혹은 트라우마 관련 연구들을 살 펴보면, 성인의 건강 및 웰빙지표에 있어서 어린 시절 부정적 생애경험에 대한 영향이 남녀에 따라 다르게 나타나는 것을 확인할 수 있다. 예를 들어, 유년기 역경을 경험한 대상자들 중 에서 남성은 성인이 되었을 때 음주 혹은 약물 남용과 같은 주 로 신체적 건강을 위태롭게 하는 행위나 반사회적 행동 등과 같이 역경의 부정적 영향을 외현적으로 발현하는 반면 여성은 우울, 불안, 혹은 정신질환 등과 같이 내면적인 형태로 나타나 는 경우들을 볼 수 있다(Almuneef, ElChoueiry, Saleheen, \& AlEissa, 2017; Chandy, Blum, \& Resnick, 1996; Fisher et al., 2009; Schilling, Aseltine, \& Gore, 2007). 물론 ACE의 성인의 건강에 대한 영향력에 있어서 실증적 연구가 밝혀낸 성별 차이가 절 대적이라고 볼 수는 없지만, 아동기 부정적 생애경험과 그 영 향에 대한 상대적인 남녀의 차이를 분석하는 것이 적어도 실 천 개입의 차원에서 보다 효과적인 방안을 마련하는 데 도움 을 줄 수 있을 것으로 본다.

따라서, 본 연구를 통하여 $\mathrm{ACE}$ 와 성인의 신체 및 정신건강 지표 간의 관계를 분석함으로써 기존 연구를 재현하는 것은 물론 더 나아가, 우리나라 선행 $\mathrm{ACE}$ 연구의 시야를 좀 더 확장 하는 의미로 아동기 부정적 생애경험과 성인의 건강 간의 관 계에 있어서 성별 차이를 심도 있게 분석하고자 한다. 본 연구 에서 분석할 연구문제는 다음과 같다.

\section{연구문제 1}

성인의 아동기 부정적 생애경험(ACEs)과 신체(주관적 건강상 태) 및 정신건강(우울증상)의 실태는 어떠한가?

\section{연구문제 2}

아동기 부정적 생애경험과 성인기의 주관적 건강상태 및 우 울증상 간의 관계는 어떠한가?

\section{연구문제 3}

아동기 부정적 생애경험이 성인의 건강에 미치는 영향에 있 어서 성별 차이가 존재하는가?

\section{Methods}

\section{연구대상}

본 연구는 성균관대학교 동아시아학술원 서베이리서치센
터에서 연구했고 한국사회과학자료원에서 2014년도에 자 료를 공개한 한국종합사회조사(Korean General Social Survey [KGSS]), 2012 데이터를 활용하였다. 한국종합사회조사 (KGSS)는 2003년을 시작으로 매년 시행되고 있고, 제주도를 포함한 전국 만 18 세 이상의 성인 남녀를 대상으로 다단계 지 역 확률 표집(multi-stage area probability sampling) 방식을 활용 하여 표본을 추출한다. 최종 표본, 즉 설문의 연구 조사 대상자 가 선정되면, 조사원이 조사가구를 직접 방문하여 대인면접을 통하여 관련 자료를 수집한다. 본 연구에서 활용하는 2012년 한국종합사회조사 자료의 응답률은 $55.8 \%$ 로 목표사례 2,500 명보다 1,104 명이 부족한 1,396 명의 응답자들로 구성되어있 다(Korea Social Science Data Archive [KOSSDA], 2014).

한국종합사회조사의 설문지는 매년 지속적으로 반복해서 물어보는 항목으로 구성된 반복핵심모듈, International Social Survey Programme (ISSP) 회원국들이 공동으로 연구 주제 및 설문 문항을 결정하고 조사하는 연차적 주제모듈, 동아시아 4 개국(한국, 중국, 일본, 대만)이 5 가지 모듈(가족, 문화, 건강, 사회 네트워크 등)들을 각 10 년 주기로 반복해서 조사하는 East Asian Social Survey (EASS) 주제 모듈, 그리고 연구자가 제 안하여 시행하는 특정주제모듈로 구성된다. 본 연구는 아동기 부정적 생애경험(ACEs)과 성인기의 신체 및 정신건강에 대한 정보를 포함한 데이터, 즉 2012년 한국종합사회조사의 연구 자 제안 특별모듈조사 ‘한국인의 정신건강 VIII’ 위주로 활용 하였다(J. Kim et al., 2019; KOSSDA, 2014). 이 연구의 조사 대 상자는 전국 만 18 세 이상의 성인 남녀 1,396 명을 포함한다.

\section{연구도구}

\section{독립변수}

\section{아동기부정적 생애경험(Adverse Childhood Experiences [ACEs])}

본 연구에서는 미국 질병관리센터(CDC, 2021)가 제시한 아 동기 부정적 생애경험(ACEs)에 대한 정의를 참고하여 2012 한국종합사회조사에서 활용 가능한 $\mathrm{ACE}$ 문항들을 이용하여 해당 변수를 조작하였다. 미국 질병관리센터(CDC, 2021)가 제시한 아동기 부정적 생애경험은 총 3 가지의 유형, 즉 학대 (abuse), 방임(neglect), 그리고 가족구성원이 겪는 어려움이나 문제(household challenges)로 분류가 된다. 이 세 가지의 유형 각각은 다수의 하위범주들로 구성이 되는데, 먼저 학대는 신 체, 정서, 그리고 성적학대가 포함이 된다. 방임은 정서 및 신 체적 방임으로 구성되고, 가족구성원의 어려움은 가정폭력에 
대한 노출, 가족 구성원의 알코올 및 약물중독, 부모의 이혼 혹 은 별거, 가족구성원의 정신질환 혹은 교도소 수감 등으로 이 루어져있다. 2012 한국종합사회조사에서는 위의 미국 미국 질병관리센터(CDC, 2021)에서 제시한 ACE 범주들 중 세 가 지 유형의 학대(신체, 정서, 성적), 정서적 방임(신체적 방임에 대한 문항은 없음), 그리고 네 가지 하위범주로 구성된 가족이 겪는 문제나 어려움(가정폭력, 가족구성원의 알코올 및 약물 중독, 부모의 이혼 혹은 별거, 가족구성원의 정신질환 및 신경 쇠약)으로 총 8 가지의 아동기(18세 이전) 부정적 생애경험을 포함했다(KOSSDA, 2014).

먼저 학대의 경우, 신체적 학대는 5 가지의 문항(예: “손바 닥으로 얼굴을 맞음.", "징벌로써 뜨거운 물, 담배 등에 화상을 입음.", “주먹으로 맞거나 발에 차임.", “징벌로써 누군가가 나 에게 던진 물건에 맞음.", "징벌로써 다른 사람에 의해 심하게 밀리거나 밀쳐짐.”)으로 이 중 한 가지라도 경험했다고 응답한 경우에 1 , 그렇지 않다는 0 으로 코딩하여 신체학대의 이분형 변수로 조작하였다. 정서적 학대는 3가지의 문항(예: “멸시나 비웃음.", "무시를 당하거나 인정받지 못한다는 느낌을 받음.", “쓸모없다는 말을 들음.")으로, 이 중 한 가지라도 경험한 경우 (그렇다[1], 그렇지 않다[0]) 정서적 학대로 정의 및 조작하였 다. 또한, 성적 학대는 한 가지의 문항(예: "누군가 나에게 성적 으로 불쾌한 육체적 접촉을 함.”)으로 응답자가 이러한 경험이 있는 경우 1 , 그렇지 않은 경우는 0 의 값을 부여했다. 다음으 로 정서적 방임에 해당하는 문항으로는 "무관심하게 방치되 거나 사랑받지 못한다는 느낌을 받음.”, “부모님/돌봄자가 내 가 필요로 하는 바를 이해해주지 못함.”으로 이 중 한 가지라 도 경험한 경우 정서적 방임으로 보았다(그렇다[1], 그렇지 않 다[0]). 마지막으로 가족구성원이 직면한 문제점이나 어려움 에 해당하는 문항들은 다음과 같다: 가정폭력(예: “가족 또는 다른 사람이 폭력을 당하는 것을 목격함.”), 알코올 및 약물 중 독(예: “부모님이나 돌보아주시던 분의 알코올 또는 약물 중 독.”, 부모님의 이혼이나 별거, 정신질환(예: “가족이 정신질 환이나 신경쇠약으로 고통 받음.”). 각각의 4 가지의 항목에서 응답자가 경험한 경우는 1 , 그렇지 않은 경우는 0 의 값을 부여 하였다.

이분화(dichotomized) 한 총 8가지의 아동기 부정적 생애경 험의 유형을 연속변수 $(M=1.44, S D=1.64$, range $=0-8)$ 로 조 작한 후 $\mathrm{ACE}$ 와 성인의 건강 간의 관계를 살펴본 다음, 본 연구 의 첫 번째 주요 목적인 단계별 용량-반응 관계(a graded doseresponse relationship)를 살펴보기 위해 Bellis 등(2017), Font와 Maguire-Jack (2016), 그리고 Slack, Font와 Jones (2017)의 연구
방법을 참고하여 이 $\mathrm{ACE}$ 연속변수를 4 개의 수준으로 분류를 하였다: 0 개 $\mathrm{ACE}, 1$ 개 $\mathrm{ACE}, 2-3$ 개 $\mathrm{ACEs}$, 그리고 4 개 혹은 그 이상의 ACEs. 이러한 ACE 연속변수의 분류법은 누적개수의 단계별 순서대로 그 심각한 수준을 살펴보는데 적합한 조작화 라 할 수 있다. 자료 분석을 위해 아동기 부정적 생애경험이 전 혀 없다고 응답한 집단, 즉 0 개의 $\mathrm{ACE}$ 에 속한 응답자들을 준 거집단(reference group)으로 설정하였다. 다음으로 본 연구의 두 번째 주요 목적으로써, 아동기 부정적 생애경험과 성인의 건강 지표 간의 관계에 있어서 성별 차이를 분석하기 위해서 $\mathrm{ACE}$ 연속변수를 그대로 활용하여 Chow test를 진행하였다.

\section{종속변수}

신체 건강: 부정적 신체 건강 상태 응답자의 주관적인 건강상 태에 대해 묻는 질문은 5점 리커트 척도(매우 좋다[1], 다소 좋다[2], 좋지도 나쁘지도 않다[3], 다소 나쁘다[4], 매우 나쁘 다[5])로 측정되었다. 이 변수를 있는 그대로 $(M=2.65, S D=$ 1.13 , range $=1-5)$ 활용하였고, 점수가 높을수록 신체적 건강상 태가 부정적이라고 볼 수 있다.

정신 건강: 우울증상 우울증상은 4점 리커트 척도(전혀 없었 다[0], 일주일 미만[1], 일주일 이상[2], 거의 매일[3])로 측정된 총 9가지의 문항을 사용하였고 그 예시들은 다음과 같다: “잠 들기 어렵거나 자꾸 깨어남, 또는 너무 많이 잠.", “피곤감, 기 력이 저하됨.", “식욕 저하 또는 과식.", "일을 하는 것에 대한 흥미나 재미가 거의 없음.", "가라앉은 느낌 우울감 또는 절망 감.", "내 자신이 나쁜 사람이라는 느낌 또는 내 자신을 실패자 라고 느끼거나, 나 때문에 나 자신이나 내 가족이 불행하게 되 었다는 느낌.", “신문을 읽거나 TV를 볼 때 집중하기 어려움.”, “남들이 알아챌 정도로 거동이나 말이 느림. 또는 반대로 너 무 초조하고 안절부절 못해서 평소보다 많이 돌아다니고 서성 거림.", "나는 차라리 죽는 것이 낫겠다는 등의 생각 또는 어떤 면에서건 내 스스로에게 상처를 주는 생각들.”이 9가지의 문 항을 활용하여 0점에서 27점으로 이루어진 연속변수로 조작 하였다 $(M=4.60, S D=4.60$, range $=0-27)$. 다시 말해서, 이 연 속변수의 값이 높을수록 우울증상의 심각성이 높다고 볼 수 있다.

\section{통제변수}

본 연구의 종속 변수인 성인기의 신체 및 정신건강에 영향을 
미칠 수 있는 통제변수로써 국내외 선행 ACE 연구의 방법론 을 참고하여 성인기의 인구사회학적인 요인들인 성별, 나이, 최종 학력, 혼인상태, 직업의 유무, 월 평균 가구 소득, 거주 지 역, 그리고 자녀의 수 등을 포함하였다. 먼저, 응답자의 성별은 남성(준거집단)은 0, 여성은 1 의 값을 부여하였고, 나이는 연속 변수(18-95)로 사용하였다. 최종 학력 수준은 세 가지의 범주, 즉 고등학교 졸업(준거집단 $=0$ ), 고등학교 졸업 미만(무학, 초 등학교 졸업, 혹은 중학교 졸업 $=1)$, 그리고 전문대학 졸업 또 는 그 이상(2)으로 구분하였다. 또한, 현재 직업이 있다고 응답 한 연구대상자를 1 , 무직이라고 답변한 집단을 0 의 값을 부여 하였고, 이와 마찬가지로 기혼인 경우를 1 , 기혼이 아닌 다른 혼인 상태(사별, 이혼, 별거, 미혼, 동거 등)를 0 으로 재 코딩하 여 이분화 하였다. 월 평균 가구 총 소득을 총 5 가지의 범주, 즉 0-200만원(준거집단), 200-400만원, 400-600만원, 600-800만 원, 그리고 800-1000만원으로 구성하였다. 응답자의 거주 지 역은 총 4개의 범주인, 큰 도시(준거집단), 큰 도시 주변, 작은 도시, 그리고 시골마을(외딴 곳 포함)로 구성되었다. 마지막으 로, 연속변수로써 응답자의 전체 자녀의 수를 포함하였다.

\section{자료분석}

모든 자료 분석은 통계 프로그램인 Stata 16 (Stata Corp LLC, College Station, Texas)을 이용하였다. 본 연구에서는 세 가지의 연구 질문을 중점적으로 분석했다. 첫 번째 질문은 "한국 만 18 세 이상의 성인 남녀의 아동기 부정적 생애경험(ACEs)과 신 체(주관적 건강상태) 및 정신건강(우울증상)의 실태는 어떠한 가?”, 두 번째 질문은 "아동기 부정적 생애경험과 성인기의 주 관적 건강상태 및 우을증상 간의 관계는 어떠한가?”, 그리고 세 번째 질문은 "아동기 부정적 생애경험이 성인의 건강에 미 치는 영향에 있어서 성별 차이가 존재하는가?”이다.

먼저, 첫 번째 연구 질문을 분석하기 위해, 기술통계(빈도 분석을 포함)를 통하여 연구대상자가 18 세 이전에 겪었던 다 양한 부정적인 생애경험(ACEs)에 대한 누적 개수와 유형별로 그 실태를 파악하였다. 이어서 기본적으로 연구대상자의 신체 및 정신건강에 대한 아동기 부정적 생애경험의 유무에 따른 통계적으로 유의미한 차이를 분석하기 위해 전체 응답자를 두 집단(ever experienced ACEs $=1$, never experienced ACEs $=0$ )으 로 나누어 빈도분석 및 t-test (연속 변수)와 카이제곱검정(이분 형 변수)을 실시하였다.

두 번째 연구질문에 대해서는 본 연구의 주요 독립변수인 아동기 부정적 생애경험(연속변수)과 성인기의 신체(주관적
인 부정적 건강상태) 및 정신건강(우울증상)과의 유의미한 상 관관계의 결과를 기반으로 선형회귀분석을 실시하였고 주요 회귀모델은 국내외 선행 $\mathrm{ACE}$ 연구의 실증적 분석 방법론을 바탕으로 성인기의 인구사회학적 요인을 통제하였고, 모든 통 계 분석은 표본으로부터 모집단의 추정치를 최대한 도출하 기 위해 서베이 가중치(2010 센서스 기준 성, 연령별 인구비례 사후 층화 가중치)를 적용하였다(KOSSDA, 2014). 또한, $\mathrm{ACE}$ 의 누적개수와 성인 건강지표 간의 단계별 용량-반응 관계(a graded dose-response relationship)를 살펴보기 위해 ACE 연속변 수를 총 4 개의 수준으로 분류한 다음 동일한 회귀분석모델을 실시하였다.

마지막으로, 세 번째 연구 질문으로, 아동기 부정적 생애 경험이 성인의 건강에 끼치는 영향력에 있어서 성별 차이를 분석하기 위해 연속변수 ACE를 이용하여 차우테스트(Chow test)를 실시하였다. 먼저, 차우테스트를 수행하기 위해 본 연 구의 주요 독립변수인 $\mathrm{ACE}$ 연속변수를 이용하여 성별 변수 $(0$ = 남성, $1=$ 여성 $)$ 와 함께 조작한 상호작용항(interaction term) 을 ACE 연속변수, 성별변수, 그리고 성인기의 인구사회학적 요인 변수들과 함께 각각의 선형회귀분석모델(우울증상, 부 정적 신체건강상태)에 적용하여 실시하였다. 각각의 회귀분 석의 결과를 토대로 차우테스트를 실시하기 위해 'test' 명령어 를 이용하여 아동기 부정적 생애경험의 성인의 건강에 대한 영향에 있어서 남녀의 차이가 존재하는지를 검증하였다.

\section{Results}

\section{연구대상자의 일반적 인구사회학적 특성 및 $\mathrm{ACE}$ 유무에 따른 차이}

Table 1은 2012년 한국종합사회조사에서 아동기 부정적 생 애경험(ACEs) 문항에 답변한 응답자의 가중 기술 통계량 (weighted descriptive statistics)을 보여준다. 먼저, 연구대상자의 일반적인 인구사회학적 특성을 살펴보면, 남성이 $49 \%$, 여성이 $51 \%$ 로 여성의 비율이 근소한 차이로 높았고 평균 연령은 44.8 세 $(r a n g e=18-95, S D=16.7)$ 이었다. 응답자의 최종 학력 수준 은, 전문대학 졸업 또는 그 이상(45.7\%)이 가장 높은 비중을 차 지하였고, 다음으로 고등학교 졸업(31.0\%), 무학, 초등학교 졸 업, 혹은 중학교 졸업(23.3\%)순으로 나타났다. 현재 직업이 있 다고 답변한 응답자는 연구대상자 전체의 $59.0 \%$, 기혼인 경우 가 $58.0 \%$ 를 차지하였다. 월 평균 가구 총 소득을 살펴보면, 전 
Table 1

Analytic Sample Descriptive Statistics: Sociodemographic Characteristics

\begin{tabular}{|c|c|c|c|c|}
\hline \multirow[b]{3}{*}{ Variables } & & & \multicolumn{2}{|c|}{ ACEs } \\
\hline & \multirow{2}{*}{\multicolumn{2}{|c|}{ Total sample }} & \multirow{3}{*}{$\begin{array}{c}\text { Yes } \\
(n=762)\end{array}$} & \multirow{3}{*}{$\begin{array}{c}\text { No } \\
(n=634)\end{array}$} \\
\hline & & & & \\
\hline & $n(\%)$ & $\begin{array}{c}M \\
\text { (range; } S D \text { ) }\end{array}$ & & \\
\hline \multicolumn{5}{|l|}{ Sociodemographics } \\
\hline \multicolumn{5}{|l|}{ Sex } \\
\hline Male (reference) & $617(49.0)$ & & $415(58.2)^{*}$ & $202(36.1)$ \\
\hline Female & $779(51.0)$ & & $347(41.8)^{*}$ & $432(63.9)$ \\
\hline Age & & $44.8(18-95 ; 16.7)$ & $42.7(15.0)^{*}$ & $47.7(18.7)$ \\
\hline \multicolumn{5}{|l|}{ Educational attainment } \\
\hline Less than high school & $475(23.3)$ & & $212(18.7)^{*}$ & $263(29.8)$ \\
\hline Highschool (reference) & $405(31.0)$ & & $237(32.7)$ & $168(28.5)$ \\
\hline More than high school & $516(45.7)$ & & $313(48.5)^{*}$ & $203(41.7)$ \\
\hline \multicolumn{5}{|l|}{ Employment } \\
\hline Employed (reference) & $756(59.0)$ & & $445(62.8)^{*}$ & $311(53.4)$ \\
\hline Unemployed & $640(41.0)$ & & $317(37.2)^{*}$ & $323(46.6)$ \\
\hline \multicolumn{5}{|l|}{ Marital status } \\
\hline Married (reference) & $831(58.0)$ & & $449(56.7)$ & $382(59.7)$ \\
\hline Other than married & $565(42.0)$ & & $313(43.3)$ & $252(40.3)$ \\
\hline \multicolumn{5}{|l|}{ Income (KRW 10,000) } \\
\hline 0-200 (reference) & $509(27.6)$ & & $250(25.0)^{*}$ & $259(31.4)$ \\
\hline $200-400$ & $419(33.4)$ & & $260(37.7)^{*}$ & $159(27.3)$ \\
\hline $400-600$ & $249(21.1)$ & & $130(19.3)$ & $119(23.6)$ \\
\hline $600-800$ & $116(9.7)$ & & $61(8.9)$ & $55(10.9)$ \\
\hline $800-1000$ & $99(8.1)$ & & $60(9.1)$ & $39(6.8)$ \\
\hline \multicolumn{5}{|l|}{ Region } \\
\hline Urban area & $326(25.9)$ & & $187(26.4)$ & $139(25.1)$ \\
\hline Suburban area & $318(25.1)$ & & $184(26.3)$ & $134(23.5)$ \\
\hline Small town & $371(27.7)$ & & $219(29.1)$ & $152(25.7)$ \\
\hline Rural or remote area & $381(21.3)$ & & $172(18.2)^{*}$ & $209(25.6)$ \\
\hline Number of children in household & & $1.6(0-9 ; 1.5)$ & $1.5(1.3)^{*}$ & $1.9(1.7)$ \\
\hline
\end{tabular}

Note. $N=1,396 . M=$ mean; $S D=$ standard deviation. Four missing observations for the income variable $(n=1,392)$.

${ }^{*} p<.05$.

체 응답자의 약 3 분의 $1(33.4 \%)$ 이 200-400만원, 200 만원 이하 (27.6\%), 400-600만원(21.1\%), 그리고 600만원 이상(17.8\%) 순 으로 나타났다. 또한 거주 지역을 살펴보면, 작은 도시(27.7\%), 큰 도시 $(25.9 \%)$, 큰 도시 주변(25.1\%), 그리고 시골마을 혹은 외딴 곳 $(21.3 \%)$ 순으로 나타났다. 마지막으로 응답자의 전체 자녀의 수는 평균적으로 1.6 명 $(\mathrm{range}=0-9, S D=1.5)$ 이었다.

뿐만 아니라, ACE의 유무에 따른 연구대상자의 인구사회 학적 특성에 있어서 그 통계적인 차이가 드러났다. 즉, $\mathrm{ACE}$ 를
경험한 집단 $(n=762)$ 과 그렇지 않은 집단 $(n=634)$ 으로 나눈 다음 이 두 하위집단의 특성에 따른 인구사회학적 변수별 실 태를 살펴보았다. $\mathrm{ACE}$ 유무에 따른 두 하위집단 간의 통계적 으로 유의미한 차이 $(p<.05$ 혹은 더 나은 수준)를 별표를 활용 하여 구별하였다. 예를 들어, $\mathrm{ACE}$ 를 겪은 집단은 여성보다는 남성의 비율이 월등히 높았고( $58.2 \%$ vs. $41.8 \%)$ 평균 연령을 낮았다(42.7 vs. 47.7). 또한, $\mathrm{ACE}$ 를 경험하지 않은 집단과 비교 하였을 때, $\mathrm{ACE}$ 를 적어도 하나라고 겪은 연구대상자들의 사 
Table 2

Adverse Childhood Experiences and Adult Health Status

\begin{tabular}{|c|c|c|c|c|}
\hline \multirow[b]{3}{*}{ Variables } & \multirow{3}{*}{\multicolumn{2}{|c|}{ Total sample }} & \multicolumn{2}{|c|}{ ACEs } \\
\hline & & & \multirow{3}{*}{$\begin{array}{c}\text { Yes } \\
(n=762)\end{array}$} & \multirow{3}{*}{$\begin{array}{c}\text { No } \\
(n=634)\end{array}$} \\
\hline & & & & \\
\hline & $n(\%)$ & $\begin{array}{c}M \\
\text { (range; } S D \text { ) }\end{array}$ & & \\
\hline \multicolumn{5}{|c|}{ Adverse childhood experiences (ACEs) } \\
\hline 0 ACE (reference group) & $634(41.5)$ & & & \\
\hline $1 \mathrm{ACE}$ & $273(19.4)$ & & & \\
\hline 2-3 ACEs & $338(26.7)$ & & & \\
\hline 4 or more ACEs & $151(12.4)$ & & & \\
\hline ACE (a continuous variable) & & $\begin{array}{c}1.44 \\
(0-8 ; 1.64)\end{array}$ & & \\
\hline \multicolumn{5}{|l|}{ Individual ACE items } \\
\hline \multicolumn{5}{|l|}{ Abuse } \\
\hline Physical abuse & $568(45.5)$ & & & \\
\hline Emotional abuse & $282(22.5)$ & & & \\
\hline Sexual abuse & $82(6.8)$ & & & \\
\hline \multicolumn{5}{|l|}{ Neglect } \\
\hline Emotional neglect & $391(30.6)$ & & & \\
\hline \multicolumn{5}{|l|}{ Family dysfunction } \\
\hline Domestic violence & $226(17.9)$ & & & \\
\hline Alcohol and other drug abuse & $81(6.3)$ & & & \\
\hline Mental illness in household & $94(7.1)$ & & & \\
\hline Divorce or separation & $88(7.8)$ & & & \\
\hline \multicolumn{5}{|l|}{ Adult health outcomes } \\
\hline \multirow[t]{2}{*}{ Depressive symptoms } & & 4.6 & $5.5^{*}$ & 3.3 \\
\hline & & $(0-27 ; 4.6)$ & (4.7) & $(4.2)$ \\
\hline \multirow{2}{*}{ Self-rated poor physical health } & & 2.6 & 2.7 & 2.6 \\
\hline & & $(1-5 ; 1.1)$ & (1.1) & $(1.2)$ \\
\hline
\end{tabular}

Note. $N=1,396 . M=$ mean; $S D=$ standard deviation.

${ }^{*} p<.05$.

회경제적 지위(교육의 정도, 취업상태 등)가 상대적으로 높음 을 알 수 있다.

\section{연구대상자의 아동기 부정적 생애경험(ACEs) 및 성인기 신체·정신건강 실태}

다음으로, 연구대상자가 만 18 세 이전에 경험했던 부정적 생 애경험(ACEs)의 실태를 누적개수(4개의 카테고리)와 유형별 로 살펴보겠다(Table 2). 먼저 아동기 부정적 생애경험이 없다 고 응답한 설문자(41.5\%)를 제외한 나머지 응답자들의 ACEs 누적개수를 살펴보면, 2-3개(26.7\%), 1개(19.4\%), 그리고 4개 혹은 그 이상 $(12.4 \%)$ 순으로 나타났다. 또한, 아동기 부정적 생애경험을 유형별로 나누어 보았을 때, 신체적 학대가 $45.5 \%$
로 가장 높은 비중을 차지하였고, 그 다음으로 정서적 방임이 $30.6 \%$, 정서적 학대가 $22.5 \%$, 가정폭력의 노출이 $17.9 \%$ 순이 었다. 마지막으로, 전체 응답자의 $7 \%$ 내외가 부모의 이혼이나 별거 $(7.8 \%)$, 가족 구성원의 정신질환 및 신경쇠약 $(7.1 \%)$, 성적 학대(6.8\%), 혹은 양육자의 알코올 또는 약물 중독(6.3\%)을 경 험했다고 답변했다.

성인기의 정신 및 신체의 건강 실태를 살펴보면, 우울증상 의 평균은 4.6 (range $=0-27, S D=4.6$ ), 주관적인 부정적 신체건 강상태의 평균은 $2.6(\mathrm{range}=1-5, S D=1.1)$ 으로 나타났다. 또 한, 연구대상자의 성인기 신체.정신 건강상태를 ACEs, 즉 아동 기 부정적 생애경험의 유무에 따라 나뉘어 비교해 보았을 때, $\mathrm{ACE} s$ 를 겪었다고 답한 응답자들 $(n=762)$ 이 그렇지 않은 집단 $(n=634)$ 보다 부정적인 정신건강을 나타내는 지표인 우울증상 
Table 3

Associations Between Adverse Childhood Experiences and Depressive Symptoms and Poor Physical Health Status in Adulthood

\begin{tabular}{|c|c|c|c|c|}
\hline & \multicolumn{2}{|c|}{ Depressive symptoms } & \multicolumn{2}{|c|}{ Poor physical health } \\
\hline & $B(S E)$ & $\beta$ & $B(S E)$ & $\beta$ \\
\hline ACE count variable & $.97(.08)^{* * *}$ & .34 & $.10(.02)^{* * *}$ & .14 \\
\hline Age & $-.02(.01)$ & -.06 & $.01(.00)^{* * *}$ & .19 \\
\hline Less than high school ${ }^{2}$ & $1.59(.42)^{* * *}$ & .14 & $.35(.10)^{* * *}$ & .13 \\
\hline Married & $-.45(.30)$ & -.05 & $.01(.07)$ & .00 \\
\hline \multicolumn{5}{|c|}{ Average monthly income (KRW 10,000$)^{3}$} \\
\hline $200-400$ & $-.84(.36)^{*}$ & -.09 & $-.35(.08)^{* * *}$ & -.14 \\
\hline $400-600$ & $-.95(.40)^{*}$ & -.08 & $-.42(.10)^{* * *}$ & -.15 \\
\hline Suburban area & $.33(.35)$ & .03 & $.16(.08)^{*}$ & .06 \\
\hline Small town & $.08(.32)$ & .01 & $.09(.08)$ & .04 \\
\hline Rural or remote area & $.20(.44)$ & .02 & $.17(.09)$ & .06 \\
\hline Number of children in household & $.05(.13)$ & .01 & $.01(.03)$ & .01 \\
\hline Constant & $3.62(.78)^{* * *}$ & & $1.95(.16)^{* * *}$ & \\
\hline$F$ & \multicolumn{2}{|c|}{$14.85^{* * *}$} & \multicolumn{2}{|c|}{$25.66^{* * *}$} \\
\hline$R$-squared & \multicolumn{2}{|c|}{.15} & \multicolumn{2}{|c|}{.20} \\
\hline Observations & \multicolumn{2}{|c|}{1,392} & \multicolumn{2}{|c|}{1,392} \\
\hline
\end{tabular}

Note. $S E$ = standard error; ACEs $=$ adverse childhood experiences.

${ }^{1}$ Reference group for sex is male. ${ }^{2}$ Reference group for the educational attainment is high school degree. ${ }^{3}$ Reference group for the average monthly household income is $0-200$ (KRW) group. ${ }^{4}$ Reference group for the region categories is urban area.

${ }^{*} p<.05 .{ }^{* *} p<.01 .{ }^{* * *} p<.001$.

의 평균정도가 통계적으로 유의미하게 높았고 그 통계적으로 유의미한 차이는 $p<.05$ 혹은 더 나은 수준이다(5.5 vs. 3.3).

\section{아동기 부정적 생애경험 $(\mathrm{ACEs})$ 과 성인의 우 울증상 및 부정적 신체건강 간의 관계}

Table 3은 아동기 부정적 생애경험(연속변수)과 성인기의 우 울증상 및 부정적 신체건강 간의 관계를 선형 회귀분석한 결 과를 보여준다. 먼저, 우울증상 회귀 모형에서 아동기 부정적 생애경험을 포함한 변수들이 성인의 우울증상의 약 $15 \%$ 정도 를 설명하고 부정적 신체건강의 경우 약 $20 \%$ 정도를 설명하 는 것으로 나타났다. 그리고 성인기의 다양한 인구사회학적 요소(성별, 나이, 최종학력, 직업의 유무, 혼인상태, 월 평균 가 구 소득, 거주 지역, 자녀의 총 수 등)를 통제하고, 연구대상자
의 아동기 부정적 생애경험의 수가 증가할수록 성인이 되었을 때 겪는 우울증상 $(\beta=.34, p<.001)$ 및 부정적 신체건강상태의 정도 $(\beta=.14, p<.001)$ 또한 증가하는 것을 알 수 있다.

또한, 본 연구의 주요 목적 중의 하나인 아동기 부정적 생애 경험의 누적개수와 성인의 신체 · 정신건강지표 간의 관계, 즉 단계별 혹은 등급별 용량-반응 관계(Felitti et al., 1998; Loxton et al., 2021; Merrick et al., 2017)를 분석하기 위해 ACE 연속변수를 4 개의 수준(0개 $\mathrm{ACE}, 1$ 개 $\mathrm{ACE}, 2-3$ 개 ACEs, 그리고 4개 혹은 그 이상)로 분류하였다. 그 다음, Table 3에서 보여준 회귀분석 모델에서 $\mathrm{ACE}$ 연속변수를 대신하여 4 개의 단계별 $\mathrm{ACE}$ 누적 개수를 포함시켜 동일하게 회귀분석모델을 실시하였다. Table 4는 아동기 부정적 생애경험의 누적개수별 순서대로 성인의 신체 및 정신건강문제에 대한 그 심각한 수준을 보여준다. 기 존의 회귀분석모델(Table 3)과 동일하게 성인기의 다양한 인구 
Table 4

A Dose-Response Relationship Between the Cumulative Number of Adverse Childhood Experiences and Adult Health Outcomes

\begin{tabular}{lcccc}
\hline & \multicolumn{2}{c}{ Depressive symptoms } & \multicolumn{2}{c}{ Poor physical health } \\
\cline { 2 - 5 } & $B(S E)$ & $\beta$ & $B(S E)$ & $\beta$ \\
\hline ACE & $1.19(.29)^{* * *}$ & .10 & $.17(.08)^{*}$ & .06 \\
4-3 ACEs & $2.35(.32)^{* * *}$ & .22 & $.20(.07)^{* *}$ & .08 \\
\hline
\end{tabular}

Note. $S E$ = standard error; ACEs = adverse childhood experiences. Reference category for ACE is 0 (never) ACE group.

${ }^{*} p<.05 .{ }^{* *} p<.01 .{ }^{* * *} p<.001$.

Table 5

Chow Test Results of Gender Differences in Adverse Childhood Experiences' Impact on Adult Health Outcomes

\begin{tabular}{ccc}
\hline Group differences & Depressive symptoms & Poor physical health \\
\hline Male vs. Female & $F(2,1390)=8.33^{* * *}$ & $F(2,1390)=8.64^{* * *}$ \\
& $\mathrm{M}<\mathrm{F}$ & $\mathrm{M}>\mathrm{F}$ \\
\hline
\end{tabular}

Note. $\mathrm{M}=$ male; $\mathrm{F}$ = female.

${ }^{* * *} p<.001$.

Table 6

Comparisons Between Male and Female Groups in Adverse Childhood Experiences' Impact on Adult Health Outcomes

\begin{tabular}{lcccccccc}
\hline & \multicolumn{3}{c}{ Depressive symptoms } & \multicolumn{3}{c}{ Poor physical health } \\
\cline { 2 - 9 } & \multicolumn{2}{c}{ Male $(n=614)$} & Female $(n=778)$ & \multicolumn{2}{c}{ Male $(n=614)$} & Female $(n=778)$ \\
\cline { 2 - 10 } & $B(S E)$ & $\beta$ & $B(S E)$ & $\beta$ & $B(S E)$ & $\beta$ & $B(S E)$ & $\beta$ \\
\hline ACE count variable & $.98(.11)^{* * *}$ & .33 & $.99(.11)^{* * *}$ & .36 & $.11(.03)^{* * *}$ & .16 & $.09(.02)^{* * *}$ & .13 \\
\hline
\end{tabular}

Note. $B=$ unstandardized regression estimates; $\beta=$ standardized estimates; $S E=$ standard error.

${ }^{* * *} p<.001$.

사회학적 요소들을 통제하고, 연구대상자의 아동기 부정적 생 애경험의 누적 개수가 높을수록 성인이 되었을 때 겪는 우울증 상 및 부정적 신체건강상태의 정도가 어린 시절 부정적 생애경 험을 겪지 않았던 집단보다 통계적으로 유의미하게 높았다. 좀 더 구체적으로 살펴보면, 성인기 우울증상은 $\mathrm{ACE}$ 의 누적개수 가 1 개 $(\beta=.10, p<.001), 2-3$ 개 $(\beta=.22, p<.001)$, 그리고 4 개 혹 은 그 이상 $(\beta=.35, p<.001)$, 부정적 신체건강상태는 $\mathrm{ACE}$ 의 누 적개수가 1 개 $(\beta=.06, p<.05), 2-3$ 개 $(\beta=.08, p<.01)$, 그리고 4 개 혹은 그 이상 $(\beta=.15, p<.001)$ 의 순서대로 그 심각한 정도가 단계별로 높아짐을 알 수 있다. 이처럼 어린 시절 부정적 생애 경험에 많이 노출될수록 성인기에 겪는 부정적인 정신 및 신체 건강의 정도가 심하게 나타난다고 볼 수 있다.

\section{아동기 부정적 생애경험(ACEs)이 성인의 건강에 미치는 영향에 있어서의 성별 차이}

지금까지 아동기 부정적 생애경험(ACEs)과 성인의 신체 및 정
신건강 간의 관계를 선형회귀분석으로 검증하였다. 하지만 Table 1 의 기술통계량에서 보여주듯이, 여성보다 남성의 ACEs 에 대한 비율이 높았기 때문에 전반적인 분석에만 그치지 않 고 좀 더 나아가, 위의 회귀분석의 결과에 있어서 남녀의 성별 에 따라 아동기의 부정적 생애경험이 각각의 성인의 건강지표 에 얼마나 다른 영향을 줄 수 있는지를 검증하기 위해 차우테 스트(Chow test)를 실시하였다. Table 5는 각 종속변수, 즉 성인 의 신체 및 정신건강지표에 있어서의 차우테스트의 결과를 보 여준다. 주목할 만한 결과는, 성인의 건강지표에 있어서 아동 기 부정적 생애경험의 영향력에 대한 남녀의 차이가 분명하 다는 것이다. 즉, 연구대상자들 중 남성보다는 여성이 우울증 상에 대한 위험이, 여성보다는 남성이 부정적 신체건강상태의 위험이 각각 높음을 알 수 있다.

더 나아가, Table 6은 차우테스트의 결과를 뒷받침 할 수 있 는 구체적인 증거를 제시한다. 먼저 성별 변인을 포함한 인 구사회학적 변수를 통제하고 남녀 두 집단을 모두 합쳐서 (pooled) 분석한 회귀모형(Table 3)과 비교하여, ACE의 우울증 
상에 대한 표준화한 회귀계수가 .34에서 남성의 집단의 경우 .33 으로 줄어들었지만 여성 집단의 경우 .36 으로 증가한 것을 볼 수 있다. 마찬가지로, 부정적 신체건강상태의 경우, 합친 모 델에서 $\mathrm{ACE}$ 의 회귀계수가 .14에서 남성 집단은 .16으로 증가 하였으나 반대로 여성 집단의 경우 13 으로 감소하는 것으로 나타났다. 즉, 여성의 경우 기존에 합친 회귀모형에서 보여준 $\mathrm{ACE}$ 의 우울증상에 대한 위험성보다 더 증가한 회귀계수를 나 타내었고 남성의 집단에서는 합친 모형보다 $\mathrm{ACE}$ 의 부정적 신 체건강상태에 대한 위험성이 더 높은 것으로 드러났다. 이는 두 집단을 합친 모델에서 성별 변인은 단순히 다른 인구사회 학적 통제변수들과 함께 포함되어있기 때문에 ACE가 성인의 건강에 미치는 영향을 분석함에 있어서 명백한 남녀 차이의 결과에 대해 해석하는 것은 무리가 있음을 암시한다. 따라서, 차우테스트의 결과에서 $\mathrm{ACE}$ 와 건강 지표 간의 유의미한 성별 의 차이를 통계적으로 검증하였고 남성과 여성 각각의 하위집 단으로 나누어 그 구체적인 회귀계수의 비교에서도 확인하였 기 때문에, 이 두 집단을 합쳐서 분석한 모형보다는 두 하위집 단을 따로 분석하는 것이 더 타당한 방법임을 증명한 것으로 판단된다.

\section{Discussion}

본 연구는 2012년도 한국종합사회조사(KGSS) 데이터를 이용 하여 18 세 이상 성인의 아동기 부정적 생애경험(ACEs)의 실태 를 파악하고, 아동기 부정적 생애경험과 성인의 신체 및 정신 건강 지표 간의 관계를 분석하였다. 더 나아가, 아동기 부정적 생애경험이 성인의 건강에 미치는 영향에 있어서 성별 차이가 존재하는지를 살펴보았다.

먼저, 연구대상자 1,396 명 중 약 $58.5 \%$ 가 어린 시절 1 개 이 상의 $\mathrm{ACE}$ 를 겪었다고 응답하였고 $\mathrm{ACE}$ 의 유형을 살펴보면, 신체적 학대가 약 $45.5 \%$ 로 가장 많은 비율을 차지하였고, 그 다음으로 정서적 방임(30.6\%), 정서적 학대(22.5\%) 순으로 나 타났다. 특히, 해외의 $\mathrm{ACE}$ 관련 선행 연구들을 살펴보면 역경 의 다양한 유형 중 신체적 학대의 비중은 약 $26 \%$ 에서 $35 \%$ 로 (Chartier et al., 2010; Font \& Maguire-Jack, 2016; Merrick et al., 2017), 우리나라의 아동기 신체적 학대의 비율이 현저히 높음 을 확인할 수 있다. 이는 현재 사회적으로 크게 이슈가 되고 있 는 여러 아동학대 사건들에서도 알 수 있듯이, 신체적으로 학 대를 당하여 아동이 크게 다친다거나 사망하는 등의 비극적인 결말로 이르게 되는 사례들이 심심치 않게 언론을 통하여 알려
지는 실정이다. 외국의 아동기 부정적 생애경험의 연구 결과들 과 비교하여 우리나라의 상대적으로 높은 신체적 학대의 비율 과 더불어 현 아동학대의 사례들을 종합적으로 보았을 때, 본 연구가 살펴본 한국 성인의 아동기 역경 실태의 결과는 학대 를 겪고 있는 아동에 대한 면밀한 실태조사 뿐만 아니라 이후 아동의 발달에 있어서 학대의 중·장기적 부정적인 영향에 대해 실증적으로 검증해야 할 필요성을 제시하는 데에 의의가 있다. 더 나아가 사회적으로 아동학대에 대한 주변의 관심뿐만 아니 라 특히 신체적 학대를 포함하여 다양한 학대의 유형 및 방임 에 대한 인식을 증진시키고 개선할 필요성을 제시한다. 다시 말해서, 부모나 양육자의 아동에 대한 가혹한 신체적 체벌과 그에 따르는 정서적 모욕은 단순히 훈육의 차원에서 벗어난 명 백한 포괄적인 개념의 학대라는 사회적으로 공통된 인식의 변 화와 공감이 필요하다. 또한 하나의 학대는 다른 유형의 학대 나 방임, 가족 내부의 여러 문제들과 동시 다발적으로 발생하 는 경우의 수가 높기 때문에(Dong, Anda, Dube, Giles, \& Felitti, 2003; Scott, Burke, Weems, Hellman, \& Carrion, 2013), e아동행 복지원시스템을 연계하여 학대로 의심되는 가정의 종합적인 방문조사 및 적합한 실천적 개입이 필요하다고 하겠다.

다음으로, 본 연구에서는 아동기 부정적 생애경험의 누 적 개수가 증가할수록 성인의 부정적인 신체 및 정신건강에 대한 위험성이 높아짐을 확인하였다(a graded dose-response relationship). 자세히 살펴보면, 어렸을 때 겪은 역경의 개수를 $0,1,2-3$, 그리고 4 개 혹은 그 이상으로 나누어보았을 때, 역경 을 겪지 않은 집단(0개)과 비교하여 우울증상(정신건강의 지 표)의 심각성은 나머지 각 단계별로 표준화한 회귀계수가 각 각 $.10, .22$, 그리고 .35 순으로 증가하였다. 마찬가지로 성인 의 부정적 신체건강의 상태 또한 $\mathrm{ACE}$ 의 개수가 1 개, 2-3개 그 리고 4 개 혹은 그 이상일 때 그 위험성이 각각 $.06, .08$, 그리고 .15 순으로 증가하는 것을 확인하였다. 이러한 분석 결과는 국 내 및 국외의 $\mathrm{ACE}$ 와 성인의 신체 및 정신건강 관련 선행연구 들과도 일치한다(Danese et al., 2009; Downey et al., 2017; Font \& Maguire-Jack, 2016; Gilbert et al., 2015; Y. H. Kim, 2017; J. Kim \& Son, 2020; M. H. Lee \& Kim, 2017; Merrick et al., 2017). 이는 역경의 유형뿐만 아니라 어린 시절 겪은 부정적 생애경 험의 누적과 성인기의 부정적인 신체 및 정신건강의 위험성에 대한 유의미한 상관관계를 보여준다. 다시 말해서, 어린 시절 겪은 누적된 부정적 생애경험이 이후 성인이 되었을 때 발현 될 수 있는 신체 및 정신건강문제로 인하여 삶의 질을 떨어뜨 릴 수 있는 중요한 위험 요인이 될 수 있음을 시사한다.

또한, 본 연구의 결과로부터 추측할 수 있는 점은 생애 초기 
인 아동기에 겪은 부정적 생애경험이 이후 청소년기, 청년기, 중년기 그리고 노년기까지의 장시간에 걸쳐서 단계적으로 그 부정적인 영향이 파급되어 결국 다양한 웰빙 지표에 대하여 좋지 않은 영향을 끼치게 될 수 있다는 것이다. 특히, 아동발달 관점에서 생각해 볼 때 아이들의 발달과업에 좋지 않은 영향 을 끼칠 수 있는 부정적 생애경험을 겪지 않는 것이 가장 바람 직하겠지만, 아동기 부정적 생애경험의 파급 효과에 대한 분 석 결과는 결국 부정적 생애경험의 발생 시, 초기에 신속한 사 정과 적절한 개입을 통하여 그 부정적 영향의 고리를 끊어야 할 필요성을 제시한다. 즉, 어린 시절에 겪은 역경이 지속적으 로 삶의 질에 부정적인 영향을 끼칠 수 없도록 초기 발견, 사 정, 그리고 개입의 삼박자가 신속하게 이루어져야 할 것이다.

더 나아가, 아동기 부정적 생애경험과 성인기의 건강 간의 관계를 분석한 결과를 통하여 추론할 수 있는 것은 생애 초기 에 겪은 어려움이 성인기 이전의 전 아동 발달 단계에서 더 근 접적인 영향(proximal effect)을 줄 수 있음을 암시한다. 다시 말 해서, 아동기 역경과 성인기의 건강 간의 문제 파악에서 이 두 개념 간의 시차가 크고 중간 시점에 대한 중요 사건의 정보가 부족함에도 불구하고 그 유의미한 영향력을 증명하였기 때문 에 이는 아동기 부정적 생애경험의 근접적인 영향을 파악할 필요성을 제시한다. 예를 들어, 유년기의 역경은 직·간접적으 로 청소년기의 행동, 사회정서 및 인지발달에 대하여 부정적 인 영향을 끼침으로써 청소년기의 발달 과업이 제대로 이루어 지지 않고 이는 결국 성인기의 다양한 결과에도 영향을 미칠 수 있음을 증명한다면 기존의 ACE 연구가 가지는 한계점을 극복하는 동시에 아동 및 청소년을 대상으로 하는 ACE 연구 에도 활력을 불어넣을 수 있을 것으로 기대한다.

마지막으로, 본 연구는 국내 $\mathrm{ACE}$ 선행연구의 시야를 좀 더 넓히고자 아동기 부정적 생애경험이 이후 성인의 건강에 끼치 는 영향에 있어서 성별 차이를 분석하였다. ACE와 성인의 건 강 지표 간의 관련성에 있어서 성별에 따른 차이를 분석한 시 도는 해외 몇몇 선행 연구들에서도 확인할 수 있다(Almuneef et al., 2017; Fuller-Thomson et al., 2013; Kelly-Irving et al., 2013). 본 연구의 분석 결과, $\mathrm{ACE}$ 의 성인기 부정적 신체건강 및 우울 증상에 대한 영향력에 있어서 통계적으로 의미 있는 성별 차 이가 검증되었다. 다시 말해서, 아동기 역경을 경험한 연구대 상자들 중 성인기의 우울증상에 대한 위험성이 남성보다는 여 성이 높았고, 성인기의 부정적 신체건강에 대한 위험성은 여 성보다는 남성의 집단에서 유의미하게 높았다. 이와 같이 아 동기 부정적 생애경험에 있어서 유의미한 성별차이의 연구결 과는 ACE와 밀접한 트라우마 관련 선행 연구들의 결과와 맥
락을 같이하는데, 일반적으로 남성보다는 여성이 피해를 입 은 경험과 관련하여 자기비판과 같이 부정적 생애경험을 내재 화한다던지 혹은 우울 및 불안의 수준이 횔씬 높거나 다른 정 신건강문제 등을 동반하는 반면(Alegria et al., 2013; Almuneef et al., 2017; Walker, Carey, Mohr, Stein, \& Seedat, 2004), 남성 은 본인의 어릴 적 겪은 부정적 생애경험과 관련하여 성인이 되었을 때 외현적 문제행동으로 표현되거나 약물 및 알코올 에 의존하는 등의 보다 신체적 건강에 위험을 줄 수 있는 행위 에 대한 위험성이 높은 것으로 밝혀졌다(Almuneef et al., 2017; Chandy et al., 1996).

따라서, 아동기 부정적 생애경험은 성인이 되었을 때 남녀 성별에 따라 발현되는 문제적 양상이 현저히 다르게 나타날 수 있다는 점을 확인할 수 있다. 이러한 연구 결과는 성인 남성 과 여성이 어떤 유형의 아동기 부정적 생애경험을 상대적으로 많이 겪었는지 혹은 남녀 각 집단이 드러내고 있는 부정적 생 애경험의 패턴을 파악할 필요성을 제기한다. 즉, 어린 시절 부 정적 생애경험을 겪은 성인들을 대상으로 문제를 파악하고 도 움을 제공하는 전 과정에서 남녀 각 집단이 가지는 부정적 생 애경험의 특성과 이를 성인기에 겪고 있는 건강상의 문제와 연관 지어 고려한다면 이는 일률적인 실천적·제도적 방안을 마련하는 차원에서 벗어나 성별 차이에 대한 이해를 바탕으 로 남녀 각 집단의 요구에 맞는 개입 방안을 계획하고 실행하 는 과정의 당위성을 뒷받침 할 수 있는 근거가 된다. 비록 성인 을 대상으로 $\mathrm{ACE}$ 의 영향력에 있어서 성별의 차이를 분석하였 고 그 결과에 대한 의의를 도출하였으나, 이는 결국 $\mathrm{ACE}$ 를 겪 은 아동 및 청소년을 대상으로 하는 개입 방안의 마련에도 도 움이 될 것으로 기대한다. 즉, 아동기 역경을 겪은 소년과 소녀 가 어떻게 다른 양상의 문제적 행태를 보이는 지에 대하여 분 석하고 이에 대하여 성별 차이에 기반한 실천적 개입을 한다 면 보다 더 효과적인 결과를 도출해 낼 수 있을 것으로 본다.

최종적으로, 본 연구는 위와 같은 의미 있는 연구 결과를 도 출했을 뿐만 아니라, 우리나라 ACE 연구의 확대 및 발전에 기 여하는 데에 의의가 있다. 특히, 우리나라 ACE 선행연구에서 는 찾아볼 수 없는 $\mathrm{ACE}$ 와 성인건강의 관계에 있어서의 성별 차이를 분석한 점과 한 연구 안에서 신체와 정신건강을 대표 하는 두 지표를 살펴보았던 점을 들 수 있다. 그럼에도 불구하 고, 본 연구의 한계점과 후속 연구에 대해 시사하는 바는 다음 과 같다.

첫째, 본 연구는 2012년도 한국종합사회조사 데이터를 이 용한 횡단자료를 바탕으로 아동기 부정적 생애경험과 성인 기 건강에 대한 관계성을 분석하였다. 다시 말해서, 독립변수 
인 아동기 부정적 생애경험과 종속변수인 성인의 건강지표가 동시에 측정이 되었기 때문에, 이 두 주요 변수간의 시간적 순 서 및 인과관계를 규명하는 데에는 한계가 따른다. 현재 국내 에서 활용 가능한 ACE 자료는 2012년도 한국종합사회조사 (KGSS)가 유일하고, 약 10 년 전 자료라는 점에서 자료의 최신 성에 있어서 제한점이 있다. 또한, 아동기와 성인기 사이의 중 간 시점에서 발생할 수 있는 중요한 사건이나 변수에 대한 정 보가 부족할 뿐만 아니라 아동기 부정적 생애경험의 영향력 을 완화 혹은 조절할 수 있는 요인에 대한 탐색이 부족하다. 비 록 성인의 다양한 인구사회학적 변인들을 통제하였음에도 불 구하고 아동기 부정적 생애경험과 이후 성인의 건강 및 웰빙 지표에 대하여 분석한 결과를 해석하는 데 한계가 있다. 이는 국내외 ACE 연구에서 자주 제기되는 한계점으로, 향후 국내 $\mathrm{ACE}$ 연구의 확대 및 발전을 위하여 종단적 연구를 설계하여 관련 데이터 구축의 필요성을 제시한다. 예를 들어, 하나의 집 단(cohort)의 아동기의 부정적 생애경험, 아동기와 성인기 사 이에서 발생할 수 있는 다양한 사건 및 경험, 그리고 성인기 건 강 및 웰빙에 대한 정보가 시간의 흐름에 따라 누적된 종단적 데이터를 활용한다면 ACE 연구의 질적인 부분 뿐만 아니라 분석 결과를 해석하는 데 있어서 보다 더 인과 추론에 대한 힘 을 실어줄 수 있을 것으로 기대한다.

이와 관련하여, 아동기 부정적 생애경험에 대한 정보 수집 에 있어서 객관적인 기록, 예를 들면, 어린 시절 아동학대나 가 정문제로 인해 공공 및 민간 기관의 시스템에 관련 정보가 입 력되어 있는 경우 등이 아닌 회고적 방식으로 보고하는 형식 이기 때문에, 아동기의 역경 경험에 대한 정보제공의 정확성 에 있어서 응답자의 편견이나 기억 오류가 적용될 가능성이 있다. 그러나 거의 모든 $\mathrm{ACE}$ 연구가 회고적 방식을 따르고 있 으므로 문제 가능성은 높지 않다고 판단된다. 하지만 좀 더 정 확한 정보 수집과 인과 관계를 규명하기 위해서 후속 연구에 서는 종단적인 데이터를 사용하여 주요 변수들 간의 시차를 두고 측정이 이루어진 $\mathrm{ACE}$ 와 성인기의 웰빙 지표 간의 관계 를 분석할 필요가 있다.

둘째, 본 연구에서는 미국 질병관리센터(CDC, 2021)가 제 시한 $\mathrm{ACE}$ 에 대한 정의를 참고하여 해당 문항들을 이용하여 독립변수를 조작하였다. 하지만, 최근 해외 $\mathrm{ACE}$ 선행연구들 을 살펴보면, $\mathrm{ACE}$ 의 정의를 기존의 전통적인 역경 경험의 유 형들(학대, 방임, 한정적인 가족 내의 문제들) 뿐만 아니라, 더 나아가 유년기의 가족의 사회경제적 수준(socioeconomic status [SES]) 또한 $\mathrm{ACE}$ 의 문항에 포함시키거나 혹은 기존의 $\mathrm{ACE}$ 와 더불어 주요한 추가적인 유년기 역경 경험의 독립변수로써 활
용하는 몇몇의 사례들을 확인할 수 있다(Braveman et al., 2018; Crouch, Jones, Strompolis, \& Merrick, 2020; Hughes et al., 2019; Y. Kim, Lee, \& Park, 2020; Shaefer, Lapidos, Wilson, \& Danziger, 2018). 이와 같은 맥락에서, Walsh, McCartney, Smith와 Armour (2019)가 총 35개의 ACE 선행연구들(다양한 해외국가들을 포 함)을 체계적으로 분석한 결과 공통적으로 아동기의 낮은 사 회경제적인 지위가 역경 경험의 가능성을 증가시키는 것으 로 드러났다. 이와 더불어, 기존의 전통적인 아동기 부정적 생 애경험의 정의에서 아동기의 사회경제적 요소를 추가하여 확장할 필요성이 있다고 제기하기도 한다(Taylor-Robinson, Straatmann, \& Whitehead, 2018). 따라서, 후속 연구에서는 $\mathrm{ACE}$ 와 밀접한 유년기의 다른 유형의 역경 경험들, 즉 빈곤이 나 가족의 경제적 어려움 등과 같은 독립변수들을 추가 혹은 $\mathrm{ACE}$ 조작화에 포함하여 한국 $\mathrm{ACE}$ 의 연구에 있어서 보다 심 층적인 분석이 가능하도록 탐색이 이루어질 필요가 있다.

마지막으로, 최근 국외의 $\mathrm{ACE}$ 연구들을 살펴보면 아동기 의 부정적 생애경험에만 초점을 맞추는 것이 아닌 강점 위주 의 관점(strength-based perspective) 혹은 회복탄력성(resilience) 의 개념을 바탕으로, 성인의 건강 및 웰빙에 있어서 아동기 역 경 경험의 부정적 영향을 완화시킬 수 있는 아동기의 긍정적 생애경험, 아동기 혹은 성인기의 개인 및 사회적 수준 차원에 서의 보호요인 등을 분석하고자 하는 학문적 관심이 증가하고 있는 추세이다(Bellis et al., 2017; Bethell et al., 2019; H. Lee et al., in press). 이와 관련하여, 아동발달 측면에서 살펴보면, 어 린 시절 겪은 부정적 생애경험이 이후 아동 및 청소년의 다양 한 발달과업(행동, 사회정서, 인지 등)에 어떠한 영향을 끼치 는 지와 같은 유년기 부정적 생애경험의 근접적인 영향을 분 석하는 시도가 필요하다. 또한, 아동기 역경에 대한 부정적인 영향력을 완화 혹은 조절할 수 있는 아동 수준의 변수(또래 관 계 경험, 아동의 회복탄력성 혹은 기질 등)에 대한 탐구를 한 다면 보다 더 심층적인 ACE 연구를 수행할 수 있을 것으로 기 대한다. 따라서, 본 연구뿐만 아니라 한국의 ACE 선행연구에 서는 아동기의 부정적 생애경험과 성인의 건강 및 웰빙 지표 간의 관계를 규명하는 데에 집중하였다면, 후속 연구에서는 $\mathrm{ACE}$ 와 성인의 웰빙에 있어서 어린 시절의 긍정적 생애경험이 나 사건, 아동기 혹은 성인기의 사회적 지지 등과 같은 변수를 이용한 조절 혹은 완화효과를 분석하는 것 또한 앞으로의 한 국 ACE 연구의 발전에 기여할 것으로 본다. 


\section{Acknowledgements}

This study was supported by the Ministry of Education of the Republic of Korea and the National Research Foundation of Korea (NRF-2016S1A3A2924375).

\section{Conflict of Interest}

No potential conflict of interest relevant to this article was reported.

\section{References}

\section{In English}

Alegria, A. A., Blanco, C., Petry, N. M., Skodol, A. E., Liu, S. M., Grant, B., \& Hasin, D. (2013). Sex differences in antisocial personality disorder: Results from the national epidemiological survey on alcohol and related conditions. Personality disorders, 4(3), 214-222. doi:10.1037/a0031681

Almuneef, M., ElChoueiry, N., Saleheen, H. N., \& Al-Eissa, M. (2017). Gender-based disparities in the impact of adverse childhood experiences on adult health: Findings from a national study in the Kingdom of Saudi Arabia. International Journal for Equity in Health, 16(90), 1-9. doi:10.1186/s12939-017-0588-9

Anda, R. F., Brown, D. W., Dube, S. R., Bremner, J. D., Felitti, V. J., \& Giles, W. H. (2008). Adverse childhood experiences and chronic obstructive pulmonary disease in adults. American Journal of Preventive Medicine, 34(5), 396-403. doi:10.1016/j.amepre.2008.02.002

Anda, R., Tietjen, G., Schulman, E., Felitti, V., \& Croft, J. (2010). Adverse childhood experiences and frequent headaches in adults. The Journal of Head and Face Pain, 50(9), 14731481. doi:10.1111/j.1526-4610.2010.01756.x

Bellis, M. A., Hardcastle, K., Ford, K., Hughes, K., Ashton, K., Quigg, Z., \& Butler, N. (2017). Does continuous trusted adult support in childhood impart life-course resilience against adverse childhood experiences-A retrospective study on adult health-harming behaviours and mental well-being. BMC Psychiatry, 17(110), 1-12. doi:10.1186/ s12888-017-1260-z

Bethell, C., Jones, J., Gombojav, N., Linkenbach, J., \& Sege, R. (2019). Positive childhood experiences and adult mental and relational health in a statewide sample: Associations across adverse childhood experiences levels. JAMA Pediatrics, 173(11), 1-12. doi:10.1001/jamapediatrics.2019.3007

Bonomi, A. E., Cannon, E. A., Anderson, M. L., Rivara, F. P., \& Thompson, R. S. (2008). Association between self-reported health and physical and/or sexual abuse experienced before age 18. Child Abuse \& Neglect, 32(7), 693-701. doi:10.1016/j.chiabu.2007.10.004

Braveman, P., Heck, K., Egerter, S., Rinki, C., Marchi, K., \& Curtis, M. (2018). Economic hardship in childhood: A neglected issue in ACE studies? Maternal and Child Health Journal, 22(3), 308-317. doi:10.1007/s10995-017-2368-y

Brown, D. W., Anda, R. F., Felitti, V. J., Edwards, V. J., Malarcher, A. M., Croft, J. B., \& Giles, W. H. (2010). Adverse childhood experiences are associated with the risk of lung cancer: A prospective cohort study. BMC Public Health, 10(20), 1-12. doi:10.1186/1471-2458-10-20

Cambron, C., Gringeri, C., \& Vogel-Ferguson, M. B. (2014). Physical and mental health correlates of adverse childhood experiences among low-income women. Health \& Social Work, 39(4), 221-229. doi:10.1093/hsw/hlu029

Centers for Disease Control and Prevention. (2021). Adverse childhood experiences; About the CDC-Kaiser ACE study; ACEs definitions. Retrieved April 4, 2021, from https:// www.cdc.gov/violenceprevention/aces/about.html

Chandy, J. M., Blum, R. W., \& Resnick, M. D. (1996). Genderspecific outcomes for sexually abused adolescents. Child Abuse \& Neglect, 20(12), 1219-1231. doi:10.1016/S01452134(96)00117-2

Chapman, D. P., Wheaton, A. G., Anda, R. F., Croft, J. B., Edwards, V. J., Liu, Y.,...Perry, G. S. (2011). Adverse childhood experiences and sleep disturbances in adults. Sleep Medicine, 12(8), 773-779. doi:10.1016/ j.sleep.2011.03.013

Chapman, D. P., Whitfield, C. L., Felitti, V. J., Dube, S. R., Edwards, V. J., \& Anda, R. F. (2004). Adverse childhood experiences and the risk of depressive disorders in adulthood. Journal of Affective Disorders, 82(2), 217-225. doi:10.1016/j.jad.2003.12.013

Chartier, M. J., Walker, J. R., \& Naimark, B. (2010). Separate and cumulative effects of adverse childhood experiences in predicting adult health and health care utilization. Child Abuse \& Neglect, 34(6), 454-464. doi:10.1016/ j.chiabu.2009.09.020

Crouch, E., Jones, J., Strompolis, M., \& Merrick, M. (2020). Examining the association between ACEs, childhood poverty and neglect, and physical and mental health: Data from two state samples. Children and Youth Services Review, 116, 1-7. doi:10.1016/j.childyouth.2020.105155

Dagnino, P., Ugarte, M. J., Morales, F., González, S., Saralegui, D., \& Ehrenthal, J. C. (2020). Risk factors for adult depression: 
Adverse childhood experiences and personality functioning. Frontiers in Psychology, 11, 594698. doi:10.3389/ fpsyg.2020.594698

Danese, A., Moffitt, T. E., Harrington, H., Milne, B. J., Polanczyk, G., Pariante, C. M.,...Caspi, A. (2009). Adverse childhood experiences and adult risk factors for age-related disease: Depression, inflammation, and clustering of metabolic risk markers. Archives of Pediatrics \& Adolescent Medicine, 163(12), 1135-1143. doi:10.1001/archpediatrics.2009.214

Dong, M., Anda, R. F., Dube, S. R., Giles, W. H., \& Felitti, V. J. (2003). The relationship of exposure to childhood sexual abuse to other forms of abuse, neglect, and household dysfunction during childhood. Child Abuse \& Neglect, 27(6), 625-639. doi:10.1016/s0145-2134(03)00105-4

Downey, J. C., Gudmunson, C. G., Pang, Y. C., \& Lee, K. (2017). Adverse childhood experiences affect health risk behaviors and chronic health of Iowans. Journal of Family Violence, 32, 557-564. doi:10.1007/s10896-017-9909-4

Dube, S. R., Fairweather, D., Pearson, W. S., Felitti, V. J., Anda, R. F., \& Croft, J. B. (2009). Cumulative childhood stress and autoimmune diseases in adults. Psychosomatic Medicine, 71(2), 243-250. doi:10.1097/PSY.0b013e3181907888

Espeleta, H. C., Sharkey, C. M., Bakula, D. M., Gamwell, K. L., Archer, C., Perez, M. N.,...Mullins, L. L. (2020). Adverse childhood experiences and chronic medical conditions: Emotion dysregulation as a mediator of adjustment. Journal of Clinical Psychology in Medical Settings, 27(3), 572-581. doi:10.1007/s10880-019-09639-x

Felitti, V. J., Anda, R. F., Nordenberg, D., Williamson, D. F., Spitz, A. M., Edwards, V.,...Marks, J. S. (1998). Relationship of childhood abuse and household dysfunction to many of the leading causes of death in adults: The adverse childhood experiences (ACE) study. American Journal of Preventive Medicine, 14(4), 245-258. doi:10.1016/S0749-3797(98)00017-8

Fisher, H., Morgan, C., Dazzan, P., Craig, T. K., Morgan, K., Hutchinson, G.,...Fearon, P. (2009). Gender differences in the association between childhood abuse and psychosis. The British Journal of Psychiatry, 194(4), 319-325. doi:10.1192/ bjp.bp.107.047985

Font, S. A., \& Maguire-Jack, K. (2016). Pathways from childhood abuse and other adversities to adult health risks: The role of adult socioeconomic conditions. Child Abuse \& Neglect, 51, 390-399. doi:10.1016/j.chiabu.2015.05.013

Fuller-Thomson, E., Filippelli, J., \& Lue-Crisostomo, C. A. (2013). Gender-specific association between childhood adversities and smoking in adulthood: Findings from a populationbased study. Public Health, 127(5), 449-460. doi:10.1016/ j.puhe.2013.01.006

Giano, Z., Wheeler, D. L., \& Hubach, R. D. (2020). The frequencies and disparities of adverse childhood experiences in the U.S. BMC Public Health, 20(1327), 1-12. doi:10.1186/s12889-020-09411-z

Gilbert, L. K., Breiding, M. J., Merrick, M. T., Thompson, W. W., Ford, D. C., Dhingra, S. S., \& Parks, S. E. (2015). Childhood adversity and adult chronic disease: An update from ten states and the district of Columbia, 2010. American Journal of Preventive Medicine, 48(3), 345-349. doi:10.1016/j.amepre.2014.09.006

Hughes, K., Bellis, M. A., Sethi, D., Andrew, R., Yon, Y., Wood, S.,...Zakhozha, V. (2019). Adverse childhood experiences, childhood relationships and associated substance use and mental health in young Europeans. The European Journal of Public Health, 29(4), 741-747. doi:10.1093/eurpub/ckz037

Ittoop, T., Jeffrey, K., Cheng, C.-I., \& Reddy, S. (2020). The relationship between adverse childhood experiences and diabetes in central Michigan adults. Endocrine Practice, 26(12), 1425-1434. doi:10.4158/EP-2020-0239

Kelly-Irving, M., Lepage, B., Dedieu, D., Bartley, M., Blane, D., Grosclaude, P.,...Delpierre, C. (2013). Adverse childhood experiences and premature all-cause mortality. European Journal of Epidemiology, 28(9), 721-734. doi:10.1007/ s10654-013-9832-9

Kim, Y. H. (2017). Associations of adverse childhood experiences with depression and alcohol abuse among Korean college students. Child Abuse \& Neglect, 67, 338-348. doi:10.1016/ j.chiabu.2017.03.009

Kim, S.-S., Jang, H., Chang, H. Y., Park, Y. S., \& Lee, D.-W. (2013). Association between childhood adversities and adulthood depressive symptoms in South Korea: Results from a nationally representative longitudinal study. BMJ Open, 3(7), 1-9. doi:10.1136/bmjopen-2013-002680

Kim, Y., Lee, H., \& Park, A. (2020). Adverse childhood experiences, economic hardship, and obesity: Differences by gender. Children and Youth Services Review, 116, 1-9. doi:10.1016/j.childyouth.2020.105214

LeardMann, C. A., Smith, B., \& Ryan, M. A. (2010). Do adverse childhood experiences increase the risk of postdeployment posttraumatic stress disorder in US Marines? BMC Public Health, 10(437), 1-8. doi:10.1186/1471-2458-10-437

Lee, H., Boyd, R., \& Slack, K. S. (in press). Adverse childhood experiences, positive childhood experiences, and adult health. Journal of the Society for Social Work and Research. doi:10.1086/712410

Loxton, D., Forder, P. M., Cavenagh, D., Townsend, N., Holliday, E., Chojenta, C., \& Melka, A. S. (2021). The impact of adverse childhood experiences on the health and health behaviors of young Australian women. Child Abuse \& Neglect, 111, 1-10. doi:10.1016/j.chiabu.2020.104771

McEwen, B. S., \& Gianaros, P. J. (2010). Central role of the brain in stress and adaptation: Links to socioeconomic 
status, health, and disease. Annals of the New York Academy of Sciences, 1186(1), 190-222. doi:10.1111/j.17496632.2009.05331.x

Merrick, M. T., Ports, K. A., Ford, D. C., Afifi, T. O., Gershoff, E. T., \& Grogan-Kaylor, A. (2017). Unpacking the impact of adverse childhood experiences on adult mental health. Child Abuse \& Neglect, 69, 10-19. doi:10.1016/ j.chiabu.2017.03.016

Racine, N., Devereaux, C., Cooke, J. E., Eirich, R., Zhu, J., \& Madigan, S. (2021). Adverse childhood experiences and maternal anxiety and depression: A meta-analysis. BMC Psychiatry, 21(28), 1-10. doi:10.1186/s12888-020-03017-w

Reuben, A., Moffitt, T. E., Caspi, A., Belsky, D. W., Harrington, H., Schroeder, F.,...Danese, A. (2016). Lest we forget: Comparing retrospective and prospective assessments of adverse childhood experiences in the prediction of adult health. Journal of Child Psychology and Psychiatry, 57(10), 1103-1112. doi:10.1111/jcpp.12621

Schilling, E. A., Aseltine, R. H. \& Gore, S. (2007). Adverse childhood experiences and mental health in young adults: A longitudinal survey. BMC Public Health, 7(30), 1-10. doi:10.1186/1471-2458-7-30

Scott, B. G., Burke, N. J., Weems, C. F., Hellman, J. L., \& Carrion, V. G. (2013). The interrelation of adverse childhood experiences within an at-risk pediatric sample. Journal of Child \& Adolescent Trauma, 6(3), 217-229. doi:10.1080/19 361521.2013.811459

Shaefer, H. L., Lapidos, A., Wilson, R., \& Danziger, S. (2018). Association of income and adversity in childhood with adult health and well-being. Social Service Review, 92(1), 69-92. doi:10.1086/696891

Shonkoff, J. P., Garner, A. S., The Committee on Psychosocial Aspects of Child and Family Health., Committee on Early Childhood, Adoption, and Dependent Care., Section on Developmental and Behavioral Pediatrics., Siegel, B. S.,...Wood, D. L. (2012). The lifelong effects of early childhood adversity and toxic stress. Pediatrics, 129(1), e232-e246. doi:10.1542/peds.2011-2663

Slack, K. S., Font, S. A., \& Jones, J. (2017). The complex interplay of adverse childhood experiences, race, and income. Health \& Social Work, 42(1), e24-e31. doi:10.1093/hsw/hlw059

Taylor-Robinson, D. C., Straatmann, V. S., \& Whitehead, M. (2018). Adverse childhood experiences or adverse childhood socioeconomic conditions? The Lancet Public Health, 3(6), e262-e263. doi:10.1016/S2468-2667(18)30094-X

Walker, J. L., Carey, P. D., Mohr, N., Stein, D. J., \& Seedat, S. (2004). Gender differences in the prevalence of childhood sexual abuse and in the development of pediatric PTSD. Archives of Women's Mental Health, 7, 111-121. doi:10.1007/ s00737-003-0039-z
Walsh, D., McCartney, G., Smith, M., \& Armour, G. (2019). Relationship between childhood socioeconomic position and adverse childhood experiences (ACEs): A systematic review. Journal of Epidemiology and Community Health, 73(12), 1087-1093. doi:10.1136/jech-2019-212738

\section{In Korean}

Kim, J., Kang, J., Kim, S., Kim, C., Park, W., Lee, Y.-S.,...Kim, S. (2019). Korean General Social Survey 2003-2018. Seoul: Sungkyunkwan University.

Kim, J., \& Son, S. (2020). Relationship between adverse childhood experiences and the risk of lifetime suicide attempts. Korean Journal of Child Studies, 41(2), 27-39. doi:10.5723/ kjcs.2020.41.2.27

Korea Social Science Data Archive. (2014). Korean General Social Survey, 2012 Code Book. Retrieved from https://kossda.snu. ac.kr/handle/20.500.12236/15420

Lee, M. H., \& Kim, Y. H. (2017). Adverse childhood experience and depressive symptoms among male and female college students: The mediating role of self-esteem. Journal of Korean Council for Children \& Rights, 21(2), 119-134. doi:10.21459/kccr.2017.21.2.119

Park, A., \& Chung, I.-J. (2018). Patterns of adverse childhood experiences and their influences on depressive symptoms, difficulty in emotion regulation, and interpersonal maladjustment. Korean Journal of Child Studies, 39(6), 8599. doi:10.5723/kjcs.2018.39.6.85

Ryu, J.-H., Jeon, J.-A., Lee, S.-J., Lee, J.-Y., Chung, I.-J., \& Yoo, M.-S. (2018). Understanding experiences of abuse and violence among children and youths $-A$ life course perspective (Report No. 2018-49). Sejong: Korea Institute for Health and Social Affairs.

Son, Y.-J., Kim, K.-H., \& Kim, J.-W. (2018). Effects of adverse childhood experience on posttraumatic stress disorder among adult victims of sexual assault. Journal of Korean Society of Child Welfare, 64, 145-172. doi:10.24300/ jkscw.2018.12.64.145

\section{ORCID}

Hana Lee http://orcid.org/0000-0002-4559-3634

Ick-Joong Chung http://orcid.org/0000-0002-3426-7956

Received February 4, 2021

Revision received May 12, 2021

Accepted May 12, 2021 